Arch Virol (2000) 145: 1339-1357

$\underset{\substack{\text { Archives of } \\ \text { Virology } \\ \text { OSpringer-Verlag } 2000 \\ \text { Printed in Austria }}}{\text { and }}$

\title{
Characterization of human symptomatic rotavirus isolates MP409 and MP480 having 'long' RNA electropherotype and subgroup I specificity, highly related to the P6[1],G8 type bovine rotavirus A5, from Mysore, India
}

\author{
M. R. Jagannath, R. Robert Vethanayagam, B. S. Yugandhar Reddy, \\ S. Raman, and C. Durga Rao \\ Department of Microbiology and Cell Biology, Indian Institute of Science, \\ Bangalore, India
}

Accepted February 4, 2000

\begin{abstract}
Summary. In an epidemiological study of symptomatic human rotaviruses in Mysore, India during 1993 and 1994, isolates MP409 and MP480 were isolated from two children suffering from severe, acute dehydrating diarrhea. Both isolates exhibited 'long' RNA pattern and subgroup I specificity suggesting the likelihood of their animal origin. Both isolates did not react with monoclonal antibodies (MAbs) specific for serotypes G1 to G6 as well as G10. To determine the genetic origin of these isolates, complete nucleotide sequences of genes encoding the outer capsid proteins VP4 and VP7, nonstructural proteins NSP1 and NSP3 and viral enterotoxin protein NSP4 from MP409 and partial sequences of genes from MP480 were determined. Comparison of the $5^{\prime}$ and $3^{\prime}$ terminal sequences of 250 nucleotides revealed complete identity of the gene sequences in both strains suggesting that MP409 and MP480 are two different isolates of a single strain. Comparison of the nucleotide and deduced amino acid sequences of VP4, VP7, NSP1 and NSP3 of MP409 with published sequences of strains belonging to different serotypes revealed that both outer capsid proteins VP4 and VP7 and NSP1 are highly related to the respective proteins from the P6[1], G8 type bovine rotavirus A5 isolated from a calf with diarrhoea in Thailand and that the NSP3 is highly homologous to that of bovine rotaviruses. The NSP4 protein showed greatest sequence identity with NSP4s belonging to the KUN genetic group to which NSP4s from human G2 type strains and bovine rotaviruses belong. MP409 and MP480 likely signify interspecies transmission of P6[1], G8 type strains from cattle to humans and represent the first P6[1] type rotaviruses isolated in humans. These and our previous studies on the asymptomatic neonatal strain I321 are of evolutionary and epidemiological significance in the context of close association of majority of the Indian population with cattle.
\end{abstract}




\section{Introduction}

Rotavirus, a member of the Reoviridae family, is the single most important aetiologic agent of severe, acute dehydrating gastroenteritis in infants and young children and in the young of many avian and mammalian species [38]. Rotavirus particles consist of triple-layered protein capsids enclosing a genome of eleven segments of double-stranded RNA [23]. The genome primarily encodes six structural and five non-structural proteins [23, 45]. VP4 and VP7 encoded by gene segments 4 and 7, 8 or 9 (depending on the strain), respectively, form the outer capsid, and VP6, the product of gene 6 forms the intermediate capsid. Segment 2 codes for the inner capsid protein VP2 that encloses the core consisting of the genome and the virion proteins VP1 and VP3. The nonstructural proteins NSP1, NSP2, NSP3, NSP4 and NSP5 are encoded by gene segments 5, 8, 7, 10 and 11, respectively [23].

The outer capsid proteins VP7 and VP4 specify two distinct serotype specificities, called the $\mathrm{G}$ and $\mathrm{P}$ serotypes, respectively. To date at least $14 \mathrm{G}$ serotypes have been identified in humans and other species [38]. Among the $14 \mathrm{G}$ serotypes, G1 to G4 are predominantly found in humans [38]. Serotypes G5, G6, G8 and G10 are usually detected in animals, but have also been detected in humans in recent years [19, 38, 54]. By serological assays, so far $11 \mathrm{P}$ serotypes have been identified [38]. Due to lack of immunological reagents, rotaviruses have also been classified into $\mathrm{P}$ genotypes based on amino acid sequence identity. VP4s showing $>89 \%$ identity are considered to belong to the same genotype, and to date at least 20 genotypes have been identified. While the $\mathrm{P}$ serotype is represented by a number immediately after $\mathrm{P}$, the genotype is indicated by a number in a square bracket [23].

Rotaviruses are also classified into groups and subgroups (SGs) based on the antigenic epitopes present on the intermediate capsid protein VP6. At least 7 groups termed A to $\mathrm{G}$ have been recognized. Group A rotaviruses constitute the major pathogens in humans as well as domestic animals [38]. Four subgroups I, II, I+II and non I/II have been identified among group A rotaviruses [28]. Rotaviruses can also be identified as 'long' or 'short' electropherotypes based on the faster or slower electrophoretic mobility of gene segment 11 in polyacrylamide gels, respectively. While human strains with 'short' RNA pattern generally exhibit subgroup I specificity, those with 'long' RNA pattern possess subgroup II VP6. In contrast, 'long' RNA pattern and subgroup I VP6 are commonly associated with animal strains [38]. Isolation of rotaviruses having 'long' RNA electropherotype and subgroup I-specific VP6 strongly suggests animal origin of the strains [28].

In the course of study of the genetic variation among Indian rotaviruses, we have previously reported the isolation and characterization of P8[11], G10 rotaviruses from a large number of asymptomatic new-born children in Bangalore $[19,22,57]$. During epidemiological studies of symptomatic human rotaviruses, we have isolated a few unusual strains with 'long' RNA electropherotype and subgroup I specificity suggesting that they are of animal origin ([2] and unpublished data). Since infection by purely heterologous rotaviruses does normally 
not result in severe disease due to host range effects, analysis of a few naturally occurring reassortants would be valuable in identifying the putative candidate gene/s involved in host range restriction and pathogenicity.

In this study, two isolates MP409 and MP480 having 'long' RNA pattern and subgroup I specificity, isolated from two children suffering from severe, acute diarrhea in Mysore, a city of tourist attraction in southern India, were subjected to nucleotide sequence analysis of genes encoding VP4, VP7, NSP1, NSP3 and NSP4 which have been implicated in different studies to be associated with important viral properties such as pathogenicity, virulence, host range restriction, plaque morphology phenotype, morphogenesis, viral RNA replication and translation $[6,9,11,15,20,34,37,49,60]$.

\section{Materials and methods}

\section{Viruses, virus isolation and adaptation to tissue culture}

In an epidemiological study during 1993 and 1994 in Mysore, two isolates from among 54 rotavirus-positive samples (representing 3.7\%) were observed to possess 'long' RNA pattern and subgroup I specificity. These two stool specimens MP409 and MP480 were collected from two children with severe acute diarrhea admitted to Cheluvamba hospital in Mysore, India. Sample MP409 was collected from a female child aged 2 years and MP480 was from a male child of 2 years and 7 months. Both children were from the same rural neighbourhood near Mysore but belonged to different families separated by a distance of half a kilometer. Residents of this locality rear cattle for their livelihood. The stool samples were processed as described previously [57], and the supernatants were stored at $-20^{\circ} \mathrm{C}$. MP409 was adapted to culture in vitro in MA104 cells. Tissue culture-grown viruses, Wa (SGII, P1A[8], G1), S2 (SGI, P1B[4], G2), RRV, SA11 (SGI, P5[3], G3), ST3 (SGII, P2A[6], G4), NCDV (SGI, P6[1], G6), WI61 (SGII, P1A[8], G9) and I321 (SGI, P8[11], G10) were used as controls in subgroup and serotype analysis.

\section{Extraction and electrophoresis of rotavirus RNA}

Procedures for extraction of viral genomic RNA from clinical samples and from viruses grown in tissue culture, electrophoresis of the RNA in polyacrylamide gels and detection of the dsRNA by staining with silver nitrate were described previously [57].

\section{Subgroup and serotype analysis}

Subgrouping ELISA and serotyping ELISA were performed as described earlier [28, 57]. For subgrouping ELISA, hyperimmune anti-RRV antiserum R2, the SGI-specific monoclonal antibody (MAb) 255/60 and SGII-specific MAb 631/9 were used. MAbs specific for serotypes G1-G6 and G10 used in serotyping ELISA were described previously [57]. All the antibodies were kindly provided by Dr. Harry B. Greenberg, Stanford University School of Medicine, Stanford, CA, USA.

\section{Cloning of genes 4, 5, 7, 9 and 10 of MP409 and MP480 by RT-PCR}

Double-stranded (ds) RNA from the cell culture-grown MP409 and the clinical isolate MP480 was purified by the method described earlier [19]. Purified dsRNA was reverse transcribed using AMV-reverse transcriptase and amplified by polymerase chain reaction (PCR) using a method previously described [51]. Gene-specific primers were used in cDNA synthesis and PCR amplification. Gene 4-specific $5^{\prime}$ and $3^{\prime}$ primers were $5^{\prime}$-CTAAGCTTCCCG 
GGCTATAAAATGC/GC/GTTC-3' ${ }^{\prime}$ and 5'-CTAAGCTTCCCGGGTCACATCC/TT- ${ }^{\prime}$, respectively. The respective primers for gene 9 were $5^{\prime}$-CTTCCCGGGCTTTAAAAGA/CGAGAAT- $3^{\prime}$ and 5'-CTTCCCGGGTCACATCA/GT/AA/CCA-3'. Gene 5-specific 5' and $3^{\prime}$ primers respectively were $5^{\prime}$-ACCCCGGGCTTTTTTTATGAAAAGTC- ${ }^{\prime}$ and $5^{\prime}$-CACCCGGGTTCACATA/TTTTTAT- $3^{\prime}$. The sequences of gene 7 -specific $5^{\prime}$ and $3^{\prime}$ terminal primers were described previously [51]. The gene 10 primers corresponded to the $5^{\prime}$ and $3^{\prime}$ regions of the ORF and the respective sequences are 5'-ATCCCGGGATGGAAAAGTTTCCGACCTC$3^{\prime}$ and $5^{\prime}$-CTTAAGCTTCATA/C/GGC/AT/CGCAGTC/TACTTC- $3^{\prime}$. Gene 10 from the asymptomatic neonatal strain I321 was also amplified using the same primers. All the primers have sites at the $5^{\prime}$ end for restriction enzymes of convenience. Rotavirus gene-specific sequences in the primers are underlined. PCR-amplified DNAs were digested with appropriate restriction enzymes and cloned into either pBluescript $\mathrm{KS}^{+}$or PUC18 vectors that were also digested with the corresponding enzymes.

\section{Nucleotide sequencing and comparative sequence analysis}

Nucleotide sequence of the cloned genes was determined by the dideoxynucleotide-mediated chain termination method [53]. At least two independent clones for each gene were used for sequencing. Complete nucleotide sequences of the genes from MP409 and only the $5^{\prime}$ and $3^{\prime}$ terminal 250 nucleotides of the genes from MP480 were determined using gene-specific and vector-specific primers as well as by sequencing of the subclones generated using internal restriction enzyme sites. The nucleotide and deduced amino acid sequences of genes of MP409 were analyzed and compared with the previously published rotaviral gene sequences in the data bases using GCG sequence analysis software. Phylogenetic analysis was carried out using the neighbour-joining method of Saitou and Nei [52], and Distances Program of the GCG package, Wisconsin. The accession numbers for the VP4, VP7, NSP1 NSP3 and NSP4 genes of strain MP409 and for the NSP4 gene of strain I321 are AF 143408, AF 141918, AF 141916, AF 141917, AF 141919 and AF 165066, respectively.

\section{Results}

\section{Electropherotype, subgroup and serotype analysis of MP409 and MP480}

Clinical isolates MP409 and MP480 showed identical 'long' RNA electropherotype. Of the two strains, MP409 was adapted to tissue culture and it grew rapidly in MA104 cells. Since the RNA from the clinical isolate MP480 was very limited, only the electrophoretic pattern of the tissue culture-grown MP409 is shown in Fig. 1. Subgroup analysis revealed that the clinical isolates as well as the cell culture-grown MP409 were of subgroup I specificity (data not shown). 'Long' RNA pattern and SGI specificity of these strains suggested that they are of animal origin [57]. In serotyping ELISA, neither MP409 nor MP480 reacted with MAbs specific for G serotypes 1-6 and 10 which further suggested the likelihood of their animal origin (data not shown).

\section{Sequence analysis of VP7 and VP4 genes of MP409}

Preliminary sequence analysis of about 250 nucleotides from the $5^{\prime}$ and $3^{\prime}$ termini of VP7 and VP4 genes of MP409 and MP480 revealed that the corresponding sequences of the two isolates were identical. This observation in conjunction with the observed identical subgroup and electropherotypic properties of the two 


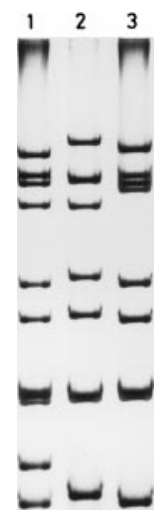

Fig. 1. Electrophoretic analysis of the cell culture-adapted MP409 strain. 1 A $\mathrm{P}$ [4], G2 type isolate 1040 (short electropherotype) 2 MP409; 3 NCDV (P6[1], G6)

strains indicated that both MP409 and MP480 represent two isolates of a single strain. Hence only MP409 was subjected to further sequence analysis as it was adapted to growth in tissue culture.

The VP7 gene of MP409 was 1062 nucleotides long with a single ORF stretching from nucleotide position 49 to 1026 and encoding a polypeptide of 326 amino acids. Comparative sequence analysis revealed that MP409 VP7 shared greatest sequence identity (94.8\%) with that of the G8 bovine strain A5 previously isolated from a calf with diarrhea in Thailand [59]. The percent amino acid sequence identities with VP7 from other G8 strains 69M, B37, NCDV-cody I-801, 678 and HAL1166 ranged between 91.7 and 93.9 and the nucleotide sequence homologies were between $83.2 \%$ and $84.6 \%$ (Table 1). A comparison of the three neutralization epitope-determining regions A, B and C of MP409 with those of all other serotypes also showed that MP409 shared greater homology in these regions with G8 strains A5, NCDV-cody I-801, 69M, B37 and 678 (Fig. 2).

The VP4 gene was 2362 nucleotides long with an open reading frame extending from nucleotide position 9 to 2340 and that encoded a protein of 776 amino acids in length. Comparison of MP409 gene 4 sequence with the published gene 4 sequences revealed that gene 4 of MP409 is highly related to the P6[1] type VP4 gene of the bovine strain A5 [59] with nucleotide and amino acid sequence identities of $95.3 \%$ and $96.1 \%$, respectively (Table 1). It also shared $92.0 \%$ and $91.0 \%$ amino acid sequence identities with the P6[1] type VP4 of the simian SA11 4f and bovine NCDV strains, respectively (Table 1). Of note, the carboxy-terminal half of the VP5* region [23] of the VP4 of SA11 4f and NCDV exhibited more divergence than that of A5 from MP409 (Fig. 3). Whereas the VP5* (aa position 250-776) region of MP409 VP4 exhibited percent amino acid identities of 97.0, 90.7 and 91.9 with that of strains A5, NCDV and SA11 4f, the corresponding amino acid percent identities of the $\mathrm{P}$ serotype determining VP8* region (position 1-250) [23] were 94.4, 91.5 and 92.3. The cysteine residues at positions 203, 216, 318 and 380 are conserved in MP409 as well as in A5, NCDV and SA11 4f.

Thus, comparison of nucleic acid and deduced amino acid sequences of VP7 and VP4 of MP409 with those of rotaviruses belonging to other serotypes clearly 
Table 1. Percent nucleotide and amino acid identities of MP409 gene sequences with those of strains belonging to the $14 \mathrm{G}$ serotypes

\begin{tabular}{|c|c|c|c|c|c|c|c|c|c|c|c|c|}
\hline \multirow[t]{2}{*}{ Strain } & \multirow{2}{*}{$\begin{array}{l}\text { Species } \\
\text { origin }\end{array}$} & \multirow{2}{*}{$\begin{array}{l}\text { Serotype/ } \\
\text { genotype }\end{array}$} & \multicolumn{2}{|c|}{ VP4 } & \multicolumn{2}{|c|}{ VP7 } & \multicolumn{2}{|c|}{ NSP1 } & \multicolumn{2}{|c|}{ NSP3 } & \multicolumn{2}{|c|}{ NSP4 } \\
\hline & & & $\mathrm{Nt}$ & AA & $\mathrm{Nt}$ & AA & $\mathrm{Nt}$ & AA & $\mathrm{Nt}$ & $\mathrm{AA}$ & $\mathrm{Nt}$ & $\mathrm{AA}$ \\
\hline Wa & Human & P1A[8], G1 & 70.6 & 71.4 & 72.8 & 75.4 & 70.4 & 57.8 & 80.8 & 83.4 & 78.5 & 81.7 \\
\hline RV5 & Human & P1B[4], G2 & 70.3 & 70.7 & NA & NA & NA & NA & NA & NA & 88.2 & 90.9 \\
\hline KUN & Human & P1B[4], G2 & NA & NA & NA & NA & NA & NA & NA & NA & 89.3 & 94.3 \\
\hline S2 & Human & P1B[4], G2 & NA & NA & NA & NA & NA & NA & 76.4 & 77.7 & 88.2 & 93.7 \\
\hline 1076 & Human & $\mathrm{P} 2 \mathrm{~A}[6], \mathrm{G} 2$ & 70.1 & 71.9 & ND & ND & NA & NA & NA & NA & 91.2 & 94.3 \\
\hline E210 & Human & P1B[4], G2 & NA & NA & NA & NA & NA & NA & NA & NA & 88.6 & 93.7 \\
\hline DS1 & Human & P1B[4], G2 & NA & NA & ND & ND & 70.5 & 55.4 & NA & NA & NA & NA \\
\hline SA11 & $\begin{array}{l}\text { Vervet } \\
\text { Monkey }\end{array}$ & P5B[2], G3 & 75.8 & 83.2 & 74.5 & 82.5 & 57.1 & 35.9 & 74.5 & 74.4 & 84.6 & 90.0 \\
\hline RRV & $\begin{array}{l}\text { Rhesus } \\
\text { Monkey }\end{array}$ & P5[3], G3 & 76.4 & 84.7 & NA & NA & 56.3 & 36.4 & 78.3 & 79.9 & 78.8 & 81.7 \\
\hline AU1 & Human & P3[9], G3 & 68.9 & 70.6 & 76.8 & 83.1 & 72.4 & 71.9 & NA & NA & 77.8 & 82.3 \\
\hline ST3 & Human & P2A[6], G4 & 70.0 & 72.6 & 74.6 & 73.9 & 70.0 & 56.0 & 81.9 & 85.0 & 77.5 & 80.0 \\
\hline $\begin{array}{l}\text { Gott- } \\
\text { fried }\end{array}$ & Porcine & P2A[6], G4 & 70.1 & 73.5 & 72.8 & 73.9 & 70.9 & 56.6 & 81.4 & 83.4 & NA & NA \\
\hline OSU & Porcine & P9[7], G5 & 75.1 & 82.0 & 75.4 & 80.7 & 70.7 & 58.2 & 81.1 & 83.8 & 77.5 & 81.7 \\
\hline Hg17 & Bovine & P?[?], G6 & NA & NA & NA & NA & NA & NA & 93.5 & 90.8 & NA & NA \\
\hline UK & Bovine & P7[5], G6 & 70.9 & 75.8 & 74.7 & 80.7 & 74.8 & 80.1 & 81.7 & 85.5 & 85.1 & 91.4 \\
\hline NCDV & Bovine & P6[1], G6 & NA & 91.0 & 75.2 & 80.4 & NA & NA & 90.2 & 91.7 & 85.3 & 90.9 \\
\hline TY-1 & Equine & P?[?], G7 & NA & NA & 66.9 & 58.9 & NA & NA & NA & NA & NA & NA \\
\hline MP409 & Human & P?[1], G8 & - & - & - & - & - & - & - & - & - & - \\
\hline A5 & Bovine & P6[1], G8 & 95.3 & 96.1 & 89.6 & 94.8 & 88.0 & 91.2 & NA & NA & NA & NA \\
\hline $\begin{array}{l}\text { SA11 } \\
4 \mathrm{f}\end{array}$ & $\begin{array}{l}\text { Vervet } \\
\text { Monkey }\end{array}$ & P6[1], G3 & 80.6 & 92.0 & NA & NA & NA & NA & NA & NA & NA & NA \\
\hline $\begin{array}{l}\text { NCDV- } \\
\text { cody }\end{array}$ & Bovine & P6[1], G8 & NA & NA & 83.2 & 93.3 & NA & NA & NA & NA & NA & NA \\
\hline 678 & Bovine & $\mathrm{P} 7[5], \mathrm{G} 8$ & NA & NA & 84.6 & 93.9 & NA & NA & NA & NA & NA & NA \\
\hline $69 \mathrm{M}$ & Human & P4[10], G8 & 74.6 & 82.7 & 84.6 & 93.8 & 70.3 & 55.6 & 75.1 & 78.7 & NA & NA \\
\hline B37 & Human & $\mathrm{P} 4[10], \mathrm{G} 8$ & NA & NA & 84.1 & 91.7 & NA & NA & NA & $\mathrm{NA}$ & NA & NA \\
\hline $\begin{array}{l}\text { HAL } \\
1166\end{array}$ & Human & P11[4], G8 & 68.8 & 71.4 & 83.9 & 93.8 & NA & NA & NA & NA & NA & NA \\
\hline WI61 & Human & P1A[8], G9 & $\mathrm{N}$ & $\mathrm{N}$ & 75.7 & 81.0 & NA & NA & 80.0 & 83.4 & NA & NA \\
\hline B223 & Bovine & $\mathrm{P} 8[11], \mathrm{G} 10$ & 61.2 & 59.2 & 74.4 & 77.9 & NA & NA & NA & NA & NA & NA \\
\hline I321 & Human & P8[11], G10 & 61.1 & 58.7 & 74.3 & 77.0 & 71.2 & 56.4 & 81.3 & 84.4 & 83.6 & 89.7 \\
\hline YM & Porcine & P9[7], G11 & 75.2 & 82.7 & 75.4 & 82.8 & 72.5 & 57.1 & NA & NA & 76.8 & 80.6 \\
\hline L26 & Human & $\mathrm{P} 1 \mathrm{~B}[4], \mathrm{G} 12$ & 70.1 & 71.1 & 72.7 & 77.3 & 71.5 & 55.0 & NA & NA & $\mathrm{NA}$ & NA \\
\hline L338 & Equine & $\begin{array}{l}\text { P12[18], } \\
\text { G13 }\end{array}$ & 77.4 & 83.6 & 73.5 & 75.5 & 58.0 & 36.6 & NA & NA & NA & NA \\
\hline FI23 & Equine & P?[12], G14 & 74.2 & 79.6 & 74.5 & 79.1 & 58.2 & 36.5 & NA & NA & NA & NA \\
\hline
\end{tabular}


established that MP409 is highly related to the P6[1], G8 type bovine rotavirus A5 and that both outer capsid proteins are likely to be of bovine origin. MP409 represents the first human isolate having the combination of serotype G8 and genotype P1 (P serotype 6) specificities. These results confirm our serological data that MP409 did not belong to any of the common human serotypes.

\section{Sequence analysis of the NSP1 and NSP3 genes}

Comparison of the $5^{\prime}$ and $3^{\prime}$ terminal sequences (250 nucleotides) of NSP1 and NSP3 genes from MP409 and MP480 revealed complete sequence identity between the two isolates suggesting identical origin of the genes in both strains. The gene 5 of MP409 was 1588 nucleotides in length and encoded a protein of 491 amino acids from nucleotide position 34 to 1506. Comparative analysis of the nucleotide and deduced amino acid sequences with the published gene 5 sequences revealed that MP409 gene 5 was highly related to that of the mutant isolate A5-10 of the bovine strain A5 [58] with $88.0 \%$ and $91.2 \%$ nucleotide and amino acid sequence identities (Table 1). Gene 5 of MP409 contained an additional adenine at position 29 in the $5^{\prime}$ UTR which was 33 nucleotides long instead of 32 nucleotides observed in many strains. While gene 5 from A5-10 encoded a truncated non-functional polypeptide of 40 amino acids in length due to the presence of a TGA termination codon at amino acid position 41, the NSP1 gene of MP409 contained a TGG condon coding for tryptophan at this position and encodes a complete NSP1 protein. Of significance, NSP1 from the human G8 strain 69M was far less related to the gene 5 of MP409 and exhibited only $70.3 \%$ and $55.6 \%$ homology at nucleotide and amino acid levels, respectively (Table 1).

Table 1 (footnote). The accession numbers for gene sequences analyzed in this table and elsewhere in the manuscript are: VP4: Wa,L34161; RV5,M32559; 1076,F28839; SA11,X14204; SA11 4f, X57319; RRV,M18736; AU1,D10970; ST3,L33895; Gottfried,M33516; OSU,X13190; I321,L07657; UK,M22306; NCDV,C31159; A5,D13395; 69M,M60600; B223,M92986; YM,M63231; L26,M58292; L338,D13399; FI23,D16342; HAL1166,L20875; VP7: Wa, K02033; DS1,E27620; SA11,V01190; AU1,D86271; ST3,X13603; Gottfried,X06759; OSU, X04613; UK,X00896; NCDV,M12394; Ty-1,L01098; A5,D01054; NCDV-cody,U14999; B37,J04334; HAL1166,L20882; 678,L20883; B223,X57852; I321,L07658; YM, M23194; L26,M58290; L338,D13549; FI23,M61876; NSP1: Wa,L18943; DS1,L18945; SA11, X14914; RRV,Z32535; AU1,D45244; ST3,U11492; Gottfried, U08431; OSU,D38153; UK, L12248; A5,D38147; 69M,D38151; I321,U08418; YM,D38154; L26,D38150; L338,D38158; FI23, D38156; NSP3: Wa,X81434; S2,X81428; SA11,X00355; SA114F,M87502; RRV, X81426; ST3,X81436; Gottfried,X81430; OSU,X81431; Hg17,X81427; UK,K02170; NCDV,X81429; 69M,X81425; WI61,X81437; I321,X81433; NSP4: Wa,K02032; RV5,U59103; KUN,D88829; S2,U59104; 1076,U59105; E210,U59107; SA11,K01138; RRV,L41247; AU1,D89873; ST3,U59110; OSU,D88831; UK,K03384; Hg17,Q82047; NCDV,X06806; I321, Q82048; YM,X69485; 69M,Q82051; FRV64,P89063; RV4,Q82033; M37,Q82034. The sequences of VP7 gene of strains 69M and WI61 were from the reference Green KM, Hoshino Y, Ikegami N (1989) 168, 429-433. NA Not available; ND not determined; Nt nucleotide; $A A$ amino acid 


\begin{tabular}{|c|c|c|c|c|c|c|}
\hline Strain & $\begin{array}{l}\text { G- } \\
\text { Type }\end{array}$ & Region A (87-101) & & & Region B (143-152) & Region C (208-221) \\
\hline P409 & 8 & EAETE I ADS SWK & $\mathrm{K} \mathrm{D} \mathrm{T}$ & & K Y N A N S E L D R & LTSDTTTFE E VATA \\
\hline 01 & 18 & $-\ldots--D--$ & - & & $\ldots \ldots-\ldots M$ & A - - - - - R \\
\hline & 8 & $\mathrm{~T} \ldots \ldots \ldots$ & - & & $-\cdots A--M$ & $\ldots \mathrm{T} \ldots \ldots$ \\
\hline $69 \mathrm{M}$ & 8 & $\mathrm{~V}-\ldots-\ldots-\ldots$ & - & - & $-\ldots-\ldots-M$ & $-\mathrm{T}_{-} \ldots \ldots$ \\
\hline B37 & 8 & $\mathrm{~V}-\ldots-\cdots$ & - & - & $-\cdots-\cdots M$ & $-\mathrm{T}_{-} \ldots \ldots$ \\
\hline 678 & 8 & $\mathrm{~V}-\ldots-\ldots-\ldots$ & - & - & $------M$ & $--\mathrm{T}-\ldots$ \\
\hline Wa & 1 & $--S-Q-N-G D--$ & - & $\mathrm{S}$ & - - DQS L - - - M & $Q-T N V D S-M I-E N$ \\
\hline DS & 2 & $--\mathrm{KN}--\mathrm{S}-\mathrm{DE}-\mathrm{E}$ & $\mathrm{EN}$ & - & R - DNT - - A A & $\mathrm{K}-\mathrm{S}-\mathrm{VN}-\mathrm{I}-\mathrm{T} \mathrm{S}$ \\
\hline 1 & 3 & $T-A--N-N S--$ & - & - & $--D---Q--M$ & $--\mathrm{S}-\mathrm{A} T-\ldots$ \\
\hline $\mathrm{S}^{\prime}$ & 4 & $S-P-Q-S-T E--$ & - & & R F V S GE - - - I & $\mathrm{Q}-\mathrm{TN}-\mathrm{A}-\cdots \mathrm{D} S$ \\
\hline $\mathrm{O}$ & 5 & $\mathrm{~N}-\mathrm{A}---\mathrm{TK}-\mathrm{T}$ & $\Gamma \mathrm{E}$ & - & $--D G--Q--M$ & $S-T-I N S-T-N A$ \\
\hline NCDV- & 6 & $\mathrm{~V}-\mathrm{S} N---\mathrm{TE}--$ & - & & - - D S T Q - - M & - I TNPD - - T - - M \\
\hline TY- & 7 & $\mathrm{~K}-\mathrm{A}-\mathrm{QMN}-\mathrm{AE}--$ & - & & $-M$ & $\mathrm{~K}-\mathrm{T}-\mathrm{VS}-\ldots \mathrm{L} \mathrm{T}-\mathrm{E}$ \\
\hline & 9 & $--S-Q-G-T E--$ & - & & - D S T L - - M & $\mathrm{T}-\mathrm{TN}-\mathrm{A} \cdots-\mathrm{AS}$ \\
\hline B & 10 & $T-R--N-N E-T$ & $\Gamma \mathrm{S}-$ & & $\mathrm{R}-\mathrm{S}$ T L K - - M & $\mathrm{G}-\mathrm{TN}-\mathrm{G}-\ldots \mathrm{R}$ \\
\hline & 1 & $\mathrm{H}-\mathrm{A}-\mathrm{Q}--\mathrm{DK}--$ & - & - & $\mathrm{Q}-\mathrm{M}$ & $--\mathrm{T}-\mathrm{PG}-\ldots-\mathrm{S}-$ \\
\hline & 12 & NSVT- - T - PD - T & $\Gamma \mathrm{H}$ & - & $-\mathrm{M}$ & $\mathrm{T}-\mathrm{T}-\mathrm{VA}-\cdots-\mathrm{N}-$ \\
\hline & 1 & $L N-D--$ & $-\mathrm{N}$ & & $-I$ & $--\mathrm{T}-\mathrm{E}-\ldots \mathrm{L}$ \\
\hline 12. & 14 & $\mathrm{~T}-\mathrm{A}-\mathrm{Q}-\mathrm{D}-\cdots$ & - & - & $--I$ & -- TNVE - - - - - S \\
\hline
\end{tabular}

Fig. 2. Comparison of the deduced amino acid sequences of the VP7 gene of MP409 strain in the variable regions VR5(A), VR7(B) and VR8(C) with those of known G8 and other $\mathrm{G}$ serotype rotaviruses. For TY-1, the numbering for the corresponding epitope regions is 91-104, 146-155 and 211-224. The accession numbers for the gene sequences compared in the figure are given in the footnote to Table 1

The NSP3 gene of MP409 was 1078 nucleotides long with an ORF encoding a protein of 314 amino acids. While the NSP3 proteins of the majority of group A rotaviruses are 313 amino acids in length (except those of SA11 4F and SA11 encoding a protein of 315 amino acids length due to insertion of two amino acids at the carboxyl terminus), the NSP3 of MP409 was longer by one amino acid due to insertion of a TCG codon encoding serine after amino acid position 233. Comparative sequence analysis revealed greatest sequence relatedness of MP409 NSP3 with that of bovine rotaviruses Hg 17 [51] and NCDV exhibiting 93.5\% and 90.2\% sequence identities at nucleotide level and $90.8 \%$ and $91.7 \%$ identities at amino acid level, respectively. The percent nucleotide and amino acid sequence homologies with other strains were less than 81.9 and 85 , respectively (Table 1). As the NSP3 gene sequence of strain A5 is not available for comparison, based on the high degree of homology of MP409 NSP3 with that of bovine strains $\mathrm{Hg} 17$ and NCDV, it is likely that the NSP3 gene in MP409 is also of bovine origin. 
Human symptomatic rotavirus isolates

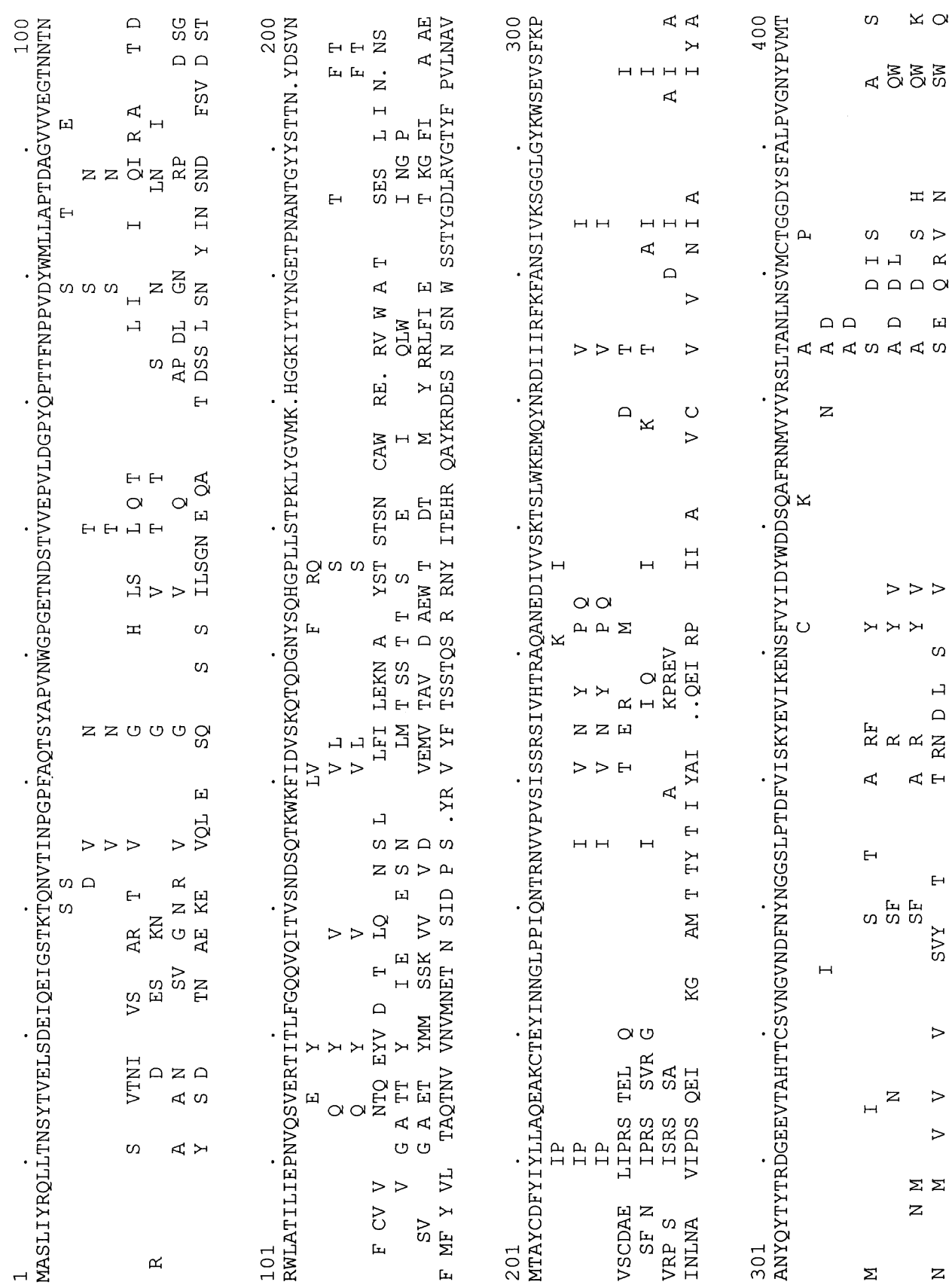

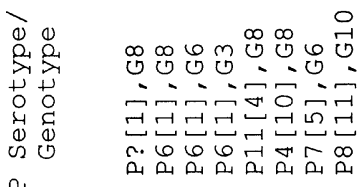

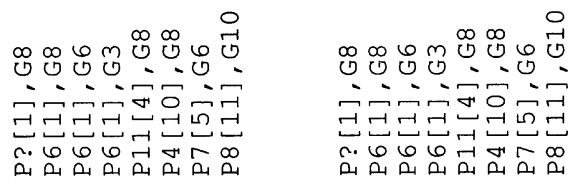

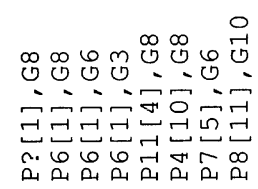

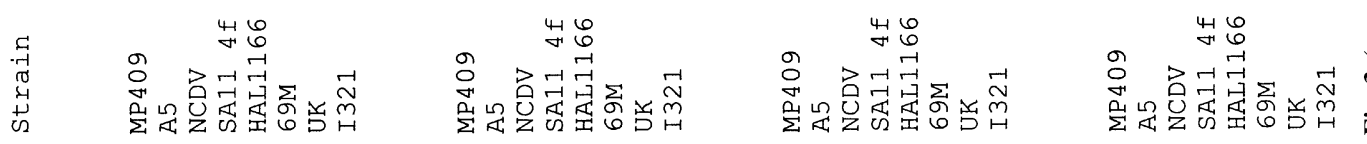




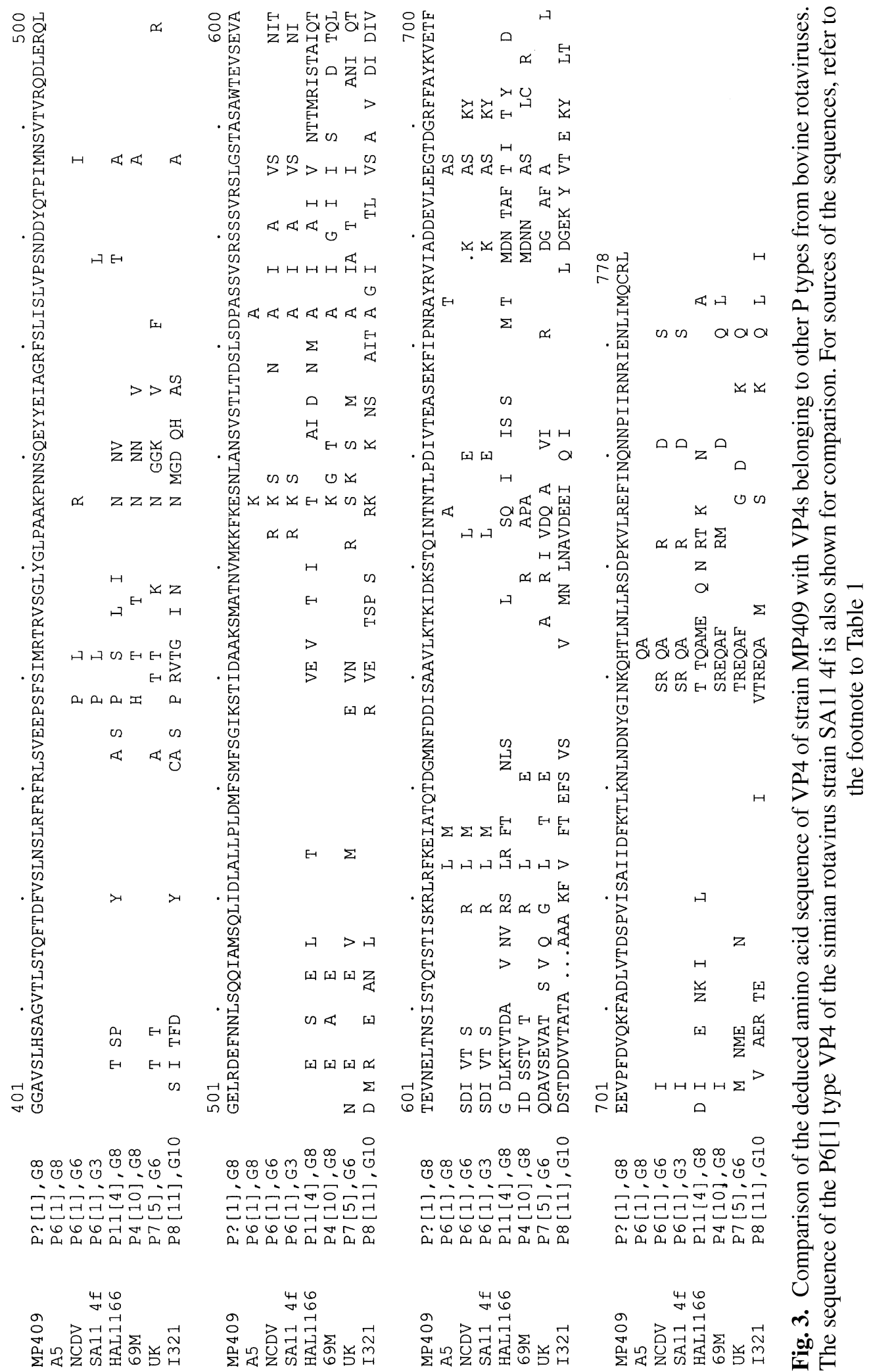




\section{Sequence analysis of the NSP4 gene}

To understand the species origin of NSP4 in MP409 and MP480 and its possible contribution to the virulent phenotype of these isolates, the complete nucleotide sequences of the protein coding region of the NSP4 gene of the isolate MP409 and the asymptomatic neonatal strain I321 as well as the $5^{\prime}$ and $3^{\prime}$ terminal sequences (250 nucleotides) corresponding to the protein coding region of the isolate MP480 were determined. The $5^{\prime}$ and $3^{\prime}$ terminal sequences of the NSP4 gene ORF between MP409 and MP480 were identical. The NSP4 gene of MP409 encoded a protein of 175 amino acids similar to that of other group A rotaviruses. It is of interest to note that the highly conserved residues phenylalanine, tyrosine and arginine at amino acid positions 33, 70 and 101, respectively, were substituted by leucine, cysteine and glutamic acid, respectively, in the MP409 NSP4. Comparative analysis revealed that MP409 NSP4 shared the highest degree of sequence identity with the NSP4 proteins of G2 serotype human rotaviruses (RV5, KUN, S2 and E210), bovine rotaviruses (UK and NCDV) as well as the human asymptomatic strains 1076 (serotype G2) and I321 (serotype G10) belonging to the KUN genetic allele (Fig. 4, Table 1, phylogram of NSP4 not shown) [18, 31, 32, 40]. The amino acid and nucleotide sequence identities of the NSP4 of these strains with that of MP409 ranged from $90.9-94.3 \%$ and $85.1-91.2 \%$, respectively (Table 1). While the NSP4 of Simian rotavirus SA11 showed 90.0\% amino acid identity with that of MP409, sequences from other strains representing the Wa, AU1 and EW NSP4 alleles exhibited less than 82.3\% identities (Table 1, Fig. 4) [32]. Within the KUN genetic group, MP409 NSP4 exhibited slightly more relatedness with that of human G2 strains with striking similarity of the region between amino acids 135 and 140. As the NSP4 sequence of strain A5 is not available, a comparison could not be carried out. Because of the high degree of relatedness between the NSP4 proteins of G2 human strains and bovine strains, a definite conclusion on the origin of the gene in MP409 and MP480 could not be drawn.

\section{Discussion}

In recent years, G6, G8 and G10 serotype rotaviruses that are the principal cause of diarrhoea in cattle $[27,29,55,56,59]$ are also being detected in humans in significant numbers $[1,7,17,19,24,26,30,57]$. Of significance are the recent studies reported from Brazil and Malawi. In the Brazilian study, $16 \%$ of the rotaviruses isolated from children suffering from diarrhoea were found to belong to G10 serotype. Also, G8 serotype strains accounted for $4 \%$ of rotavirus diarrhoea in that study [54]. In an epidemiological study in Malawi, a striking $42 \%$ of rotavirus isolates from children with diarrhoea were of P[6], G8 type and another 9\% were of P[4], G8 specificity [17]. Thus G8 strains alone accounted for more than $50 \%$ of rotavirus diarrhoea in the Malawi study. Further, seroepidemiological surveys have demonstrated the presence of G8-specific antibody in South American and Indian children [13, 39]. Serotype G8 strains have also been detected in horse [35] and pigs [27]. Table 2 describes the G8 


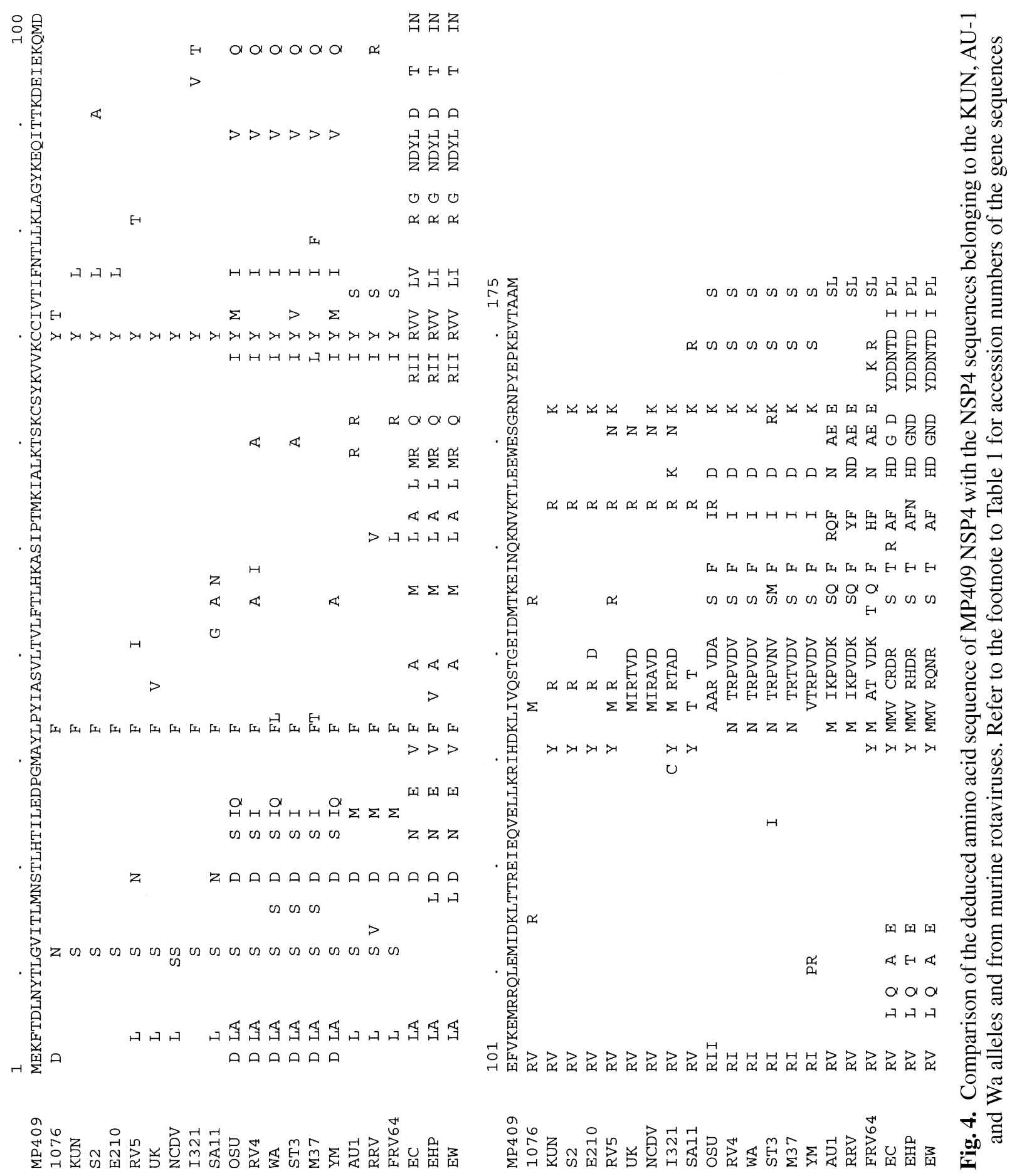


Table 2. Properties of G8 serotype strains identified so far

\begin{tabular}{|c|c|c|c|c|c|c|}
\hline Strain & $\begin{array}{l}\text { Species } \\
\text { origin }\end{array}$ & $\begin{array}{l}\text { Electro- } \\
\text { pherotype }\end{array}$ & Subgroup & $\begin{array}{l}\text { Country } \\
\text { of origin }\end{array}$ & $\begin{array}{l}\text { Serotype/ } \\
\text { genotype }\end{array}$ & Reference \\
\hline $\mathrm{J} 2538$ & Bovine & Long & I & Scotland & P6[1], G8 & {$[56]$} \\
\hline A5 & Bovine & Long & I & Thailand & $\mathrm{P} 6[1], \mathrm{G} 8$ & [59] \\
\hline NCDV-cody & Bovine & Long & I & US & P6[1], G8 & {$[16,43]$} \\
\hline BRV-14 \& BRV-15 & Bovine & Long & I & Japan & P6[1], G8 & {$[55]$} \\
\hline $26 / 94$ & Equine & Long & - & UK & $\mathrm{P}[1], \mathrm{G} 8$ & [35] \\
\hline 678 & Bovine & Long & I & Scotland & $\mathrm{P} 7[5], \mathrm{G} 8$ & [47] \\
\hline 69M, B37 \& B38 & Human & Supershort & I & Indonesia & $\mathrm{P} 4[10], \mathrm{G} 8$ & {$[3,44]$} \\
\hline $\begin{array}{l}\text { HAL1166, HAL1271 \& } \\
\text { HAL } 8590\end{array}$ & Human & Long & I & Finland & $P[14], G 8$ & {$[26]$} \\
\hline PA171 & Human & Long & II & Italy & P?, G8 & [26] \\
\hline HMG89 & Human & Short & I & Nigeria & P?, G8 & {$[1]$} \\
\hline Malawi isolates & Human & Short & - & Malawi & $\begin{array}{l}\mathrm{P}[6], \mathrm{G} 8 \& \\
\mathrm{P}[4] \mathrm{G} 8\end{array}$ & [17] \\
\hline EGY1850 \& EGY2295 & Human & Long & I & Egypt & $\mathrm{P}[14], \mathrm{G} 8$ & {$[30]$} \\
\hline MP409 \& MP480 & Human & Long & I & India & $\mathrm{P}[1], \mathrm{G} 8$ & $\begin{array}{l}\text { Present } \\
\text { study }\end{array}$ \\
\hline
\end{tabular}

strains characterized so far from humans and animals in different regions of the world.

Analysis of some of the human G8 strains revealed significant genetic relatedness to bovine rotaviruses regardless of their differences in $\mathrm{G}$ serotype specificities suggesting that bovine rotaviruses and human G8 strains could have originated from a common ancestor or that the human G8 strains could have been derived from bovine strains by genome reassortment with $\mathrm{G} 2$ human strains in nature [12, 46]. P serotype/genotype analysis of some of the G6 and G8 human strains revealed that the VP4s in human strains are different from those found in the bovine counterparts. Thus the Italian G6 type human isolates PA151 and PA169 contained P3[9] and P11[14] type VP4, respectively [36, 43, 47, 55, 56]. In contrast, the G8 human strains 69M, B37 and B38 with supershort RNA electropherotype, isolated in Indonesia, possessed P4[10] type VP4 [42] and the Finnish G8 isolates HAL1166, HAL1271 and HAL8590 as well as the Egyptian G8 isolates EGY1850 and EGY2295 contained VP4 of P11[14] type (Table 2) [30, 33]. The P types of human G8 strains PA171 isolated in Italy [26] and HMG89 isolated in Nigeria [1] are yet to be established. The large number of G8 serotype strains belonging to two $\mathrm{P}$ genotypes, $\mathrm{P}[6]$ and $\mathrm{P}[4]$, isolated in Blantyre, Malawi and possessing 'short' RNA electropherotypes, further support the hypothesis of the origin of human G8 strains by reassortment between human G2 and bovine G8 strains. Based on the present results, MP409 and MP480 likely represent isolates of a single P6[1], G8 bovine strain being transmitted from cattle to humans.

Though $\mathrm{G}$ and $\mathrm{P}$ type analysis is useful in characterization of rotaviruses, detailed sequence analysis of the genomes of naturally selected unusual rota- 
viruses/reassortants is required to identify genes that determine host range restriction and pathogenicity phenotype between bovine and human strains. The observation that the so far characterized human G6 and G8 strains possessed VP4s that are of non-bovine origin suggests an association of VP4 with host range restriction and/or pathogenicity phenotype. However, both the outer capsid proteins of the Indian asymptomatic neonatal strain I321 and of the symptomatic strains MP409 and MP480 are derived from bovine rotaviruses belonging to different serotype specificities. It is of significance to note that the VP4 sequence in MP409 is not identical to other P6[1] type VP4s from A5 and NCDV and contained several amino acid substitutions. In the context of the findings that VP4 determines pathogenicity and host restriction and that single amino acid substitutions in porcine rotavirus VP4 markedly influence the pathogenicity phenotype of the virus [10, 14, 15, 37, 49], the observed amino acid substitutions at several positions in the VP4 of MP409 and MP480 could contribute to the host range restriction and pathogenicity properties of these predominantly bovine strains in humans.

NSP4 has been identified as the intracellular receptor for subviral particles during virus morphogenesis with membrane destabilizing properties and has been implicated as possible viral enterotoxin, inducing diarrhoea by stimulating chloride ion secretion through a calcium-dependent signalling pathway involving interaction with an yet to be identified putative receptor on the intestinal epithelial cells $[5,6,8,48,61]$. A peptide spanning a region overlapping the $\mathrm{Ca}^{2+}$-binding and VP4-interaction domains (position 114-135) was suggested to be sufficient to cause diarrhoea in a newborn mouse model system [6] and certain mutations in this region and the adjacent region between amino acid positions 135 and 140 were suggested to correlate with the virulence phenotype of the strains presumably due to the changes in the structure of the C-terminal region that affects interaction with yet unidentified host cell proteins $[6,64]$. However, there have been conflicting reports regarding the enterotoxigenic activity of NSP4. Comparison on a wider scale of sequences of NSP4 from various strains failed to show an absolute correlation between the sequence and the symptomatic/asymptomatic character of the virus [18, 31, 32, 40]. In this context, as seen in Fig. 4, the NSP4 of the asymptomatic strain 1076 differed only at 3 positions in the entire carboxy terminal half ofthe protein from that of the virulent MP409. Further, the attenuated phenotype of a vaccine strain derived from the virulent wild-type human rotavirus (strain 89-12) did not correlate with mutations in the NSP4 gene [62]. In addition, Angel et al. [4] have concluded that a homologous NSP4 of strain EC did not play a dominant role in inducing diarrhoea in mice.

Newton et al. [48] have identified a cationic amphipathic helical domain between amino acid residues 55 and 72 that exhibited membrane destabilization activity in cells in vitro and proposed this region to be critical for cytopathic effect of NSP4. The apparent viral virulence mediated by NSP4 may result from its membrane destabilization function during outer capsid assembly and virus budding into the lumen of the endoplasmic reticulum and from its effects on cellular 
calcium levels at late stages of the viral replication cycle, rather than from its putative role as an enterotoxin.

Our previous studies on the P8[11], G10 type asymptomatic neonatal strain I321 as well as genetic and comparative sequence analysis studies by others showed a clustering of NSP1 sequences according to species origin and suggested a role for NSP1 and NSP3 as determinants of host range restriction of rotaviruses $[11,19,21,41,51,63]$. Further, heterologous NSP1 did not affect replication kinetics in vivo [9]. The present observation that NSP1 and NSP3 in MP409 and MP480 are of bovine origin suggests that both these proteins are not major determinants of host specificity, at least in this study between human and bovine rotaviruses. Further, NSP1 is unlikely to be associated with virulence phenotype since asymptomatic neonatal strains do not have a common NSP1 sequence [50].

To date, rotaviruses having P6[1] type VP4 have not been reported in humans. The present study shows for the first time that P6[1], G8 strains commonly found in cattle can replicate in humans and cause disease. Detailed epidemiological studies on rotaviruses in India, though limited, and restricted to large cities, revealed persistent predominance of unique bovine-human reassortant rotaviruses in nurseries $[20,22,57]$. Considering the close association of majority of the rural population with cattle and extensive use of cattle waste as manure and fuel as well as in various Indian traditions in rural settings in India, the present study is of epidemiological importance and signifies the need for study of rotaviruses in rural population.

\section{Acknowledgements}

This work was supported by a grant from the Department of Biotechnology, Government of India, through the Indo-US Vaccine Action Programme. The excellent technical help of Ms. K. S. Nagalakshmi is acknowledged.

\section{References}

1. Adah MI, Rohwedder A, Olaleyle OD, Werchau H (1997) Nigerian rotavirus serotype 8 could not be typed by PCR due to nucleotide mutation at the $3^{\prime}$ end of the primer binding site. Arch Virol 142: 1881-1 887

2. Aijaz S, Gowda K, Jagannath HV, Reddy RR, Maiya PP, Ward RL, Greenberg HB, Raju M, Babu A, Rao CD (1996) Epidemiology of symptomatic human rotaviruses in Bangalore and Mysore, India, from 1988 to 1994 as determined by electropherotype, subgroup and serotype analysis. Arch Virol 141: 715-726

3. Albert MJ, Unicomb LE, Bishop RE (1987) Cultivation and characterization of human rotaviruses with "supershort" RNA patterns. J Clin Microbiol 25: 183-185

4. Angel J, Tang B, Feng N, Greenberg HB, Bass D (1998) Studies of the role for NSP4 in the pathogenesis of homologous murine rotavirus diarrhoea. J Infect Dis 177: 455-458

5. AU K-S, Chan W-K, Burns JW, Estes MK (1989) Receptor activity of rotavirus nonstructural glycoprotein NS28. J Virol 63: 4 553-4 562

6. Ball JM, Tian P, Zeng CQ-Y, Morris AP, Estes MK (1996) Age-dependent diarrhea induced by a rotaviral nonstructural glycoprotein. Science 272: 101-104

7. Beards G, Xu L, Ballard A, Desselberger U, McCrae MA (1992) A serotype 10 human rotavirus. J Clin Microbiol 30: 1432-1 435 
8. Bergman CC, Morass D, Poruchynsky MS, Atkinson PH, Bellamy AR (1989) Topology of the nonstructural rotavirus receptor glycoprotein NS28 in the rough endoplasmic reticulum. EMBO J 8: 1695-1 703

9. Bridger JC, Dhaliwal W, Adamson MJ, Howard CR (1998) Determinants of rotavirus host range restriction - A heterologous bovine NSP1 gene does not affect replication kinetics in the pig. Virology 245: 47-52

10. Bridger JC, Tauscher GI, Desselberger U (1998) Viral determinants of rotavirus pathogenicity in pigs: evidence that the fourth gene of a porcine rotavirus confers diarrhoea in the homologous host. J Virol 72: 6929-6931

11. Broome RL, Vo PT, Ward RL, Clark HF, Greenberg HB (1993) Murine rotavirus genes encoding outer capsid proteins VP4 \& VP7 are not major determinants of host range restriction and virulence. J Virol 67: 2448-2 455

12. Browning GF, Snodgrass DR, Nakagomi O, Kaga E, Sarasini A, Gerna G (1992) Human and bovine serotype G8 rotaviruses may be derived by reassortment. Arch Virol 125: $121-128$

13. Brussow H, Sidoti J (1991) Antibody to serotype 8 rotavirus in Ecuadorian and German children. Epidemiol Infect 106: 415-420

14. Burke B, Bridger JC, Desselberger U (1994) Temporal correlation between a single amino acid change in the VP4 of a porcine rotavirus and a marked change in pathogenicity. Virology 202: 754-759

15. Burke B, McCrae MA, Desselberger U (1994) Sequence analysis of two porcine rotaviruses differing in growth in vitro and in pathogenicity: distinct VP4 sequences and conservation of NS53, VP6 and VP7 genes. J Gen Virol 75: 2 205-2 212

16. Chang KO, Parwani AV, Saif LJ (1995) Comparative nucleotide and deduced amino acid sequence analysis of the NCDV cody (I-801) strain of group A bovine rotavirus. Arch Virol 140: 1279-1 283

17. Cunliffe NA, Gondwe JS, Broadhead RL, Molyneux ME, Woods PA, Bresee JS, Glass RI, Gentsch JR, Hart CA (1999) Rotavirus G and P types in children with acute diarrhea in Blantyre, Malawi from 1997 to 1998. Predominance of novel P(6)G8 strains. J Med Virol 57: 308-312

18. Cunliffe NA, Woods PA, Leite JPG, Das BK, Ramachandran M, Bhan MK, Hart CA, Glass RI, Gentsch JR (1997) Sequence analysis of NSP4 gene of human rotavirus allows classification into two main genetic groups. J Med Virol 53: 41-50

19. Das M, Dunn SJ, Woode GN, Greenberg HB, Rao CD (1993) Both surface proteins (VP4 and VP7) of an asymptomatic neonatal rotavirus strain (I321) have high levels of sequence identity with the homologous proteins of a serotype 10 bovine rotavirus. Virology 194: 374-379

20. Das BK, Gentsch JR, Cicirello HG, Woods PA, Gupta A, Ramachandran M, Kumar R, Bhan MK, Glass RI (1994) Characterization of rotavirus strains from newborns in New Delhi, India. J Clin Microbiol 32: 1820-1 822

21. Dunn SJ, Cross TL, Greenberg HB (1994) Comparison of the rotavirus nonstructural protein NSP1 (NS53) from different species by sequence analysis and northern blot hybridization. Virology 203: 178-183

22. Dunn SJ, Greenberg HB, Ward RL, Nakagomi O, Burns JW, Vo PT, Pax KA, Das M, Gowda K, Rao CD (1993) Serotypic and genotypic characterization of human serotype 10 rotaviruses from asymptomatic neonates. J Clin Microbiol 31: 165-169

23. Estes MK (1996) Rotaviruses and their replication. In: Fields BN, Knipe DM, Howley PM, Chanock RM, Melnick JL, Monath TP, Roizman B, Straus SE (eds) Fields Virology, Vol. 2, 3rd ed. Lippincott-Raven Press, Philadelphia, pp 1625-1 655

24. Gerna G, Sears J, Hoshino Y, Steele AD, Nakagomi O, Sarasini A, Flores J 
(1994) Identification of a new VP4 serotype of human rotaviruses. Virology 200: 66-71

25. Gerna G, Sarasini A, Parea M, Arista S, Miranda P, Brussow H, Hoshino Y, Flores J (1992) Isolation and characterization of two distinct human rotavirus strains with G6 specificity. J Clin Microbiol 30: 9-16

26. Gerna G, Sarasini A, Zentilin L, DiMatteo A, Miranda P, Parea M, Battaglia M, Milanesi G (1990) Isolation in Europe of 69M-like (serotype 8) human rotavirus strains with either subgroup I or II specificity and a long RNA electropherotype. Arch Virol 112: $27-40$

27. Gouvea V, Santos N, Timenetsky MC (1994) Identification of bovine and porcine rotavirus $\mathrm{G}$ types by PCR. J Clin Microbiol 32: 1338-1 340

28. Greenberg HB, McAuliffe V, Valdesuso J, Wyatt R, Flores J, Kalica A, Hoshino Y, Singh N (1983) Serological analysis of the subgroup protein of rotavirus using monoclonal antibodies Infect Immun 39: 91-99

29. Hardy ME, Gorziglia M, Woode GN (1992) Amino acid sequence analysis of bovine rotavirus B223 reveals a unique outer capsid protein VP4 and confirms a third bovine VP4 type. Virology 191: 291-300

30. Holmes JL, Kirkwood CD, Gerna G, Clemens JD, Rao MR, Naficy AB, Abu-Elyazeed R, Savarino SJ, Glass RI, Gentsch JR (1999) Characterization of unusual G8 rotavirus strains isolated from Egyptian children. Arch Virol 144: 1381-1 396

31. Horie Y, Masamune O, Nakagomi O (1997) Three major alleles of rotavirus NSP4 proteins identified by sequence analysis. J Gen Virol 78: 2341-2 346

32. Horie Y, Nakagomi O, Koshimura Y, Nakagomi T, Suzuki Y, Oka T, Sasaki S, Matsuda Y, Watanabe S (1999) Diarrhoea induction by rotavirus NSP4 in the homologous mouse model system. Virology 262: 398-407

33. Hoshino Y, Jones RW, Kapikian AZ (1998) Serotypic characterization of outer capsid spike protein VP4 of vervet monkey rotavirus SA11 strain. Arch Virol 143: 1 233-1 244

34. Hoshino Y, Saif LI, Kang SY, Sereno MM, Chen WK, Kapikian AZ (1995) Identification of group A rotavirus genes associated with virulence of a porcine rotavirus and host range restriction of a human rotavirus in the gnotobiotic piglet model. Virology 209: 274-280

35. Isa P, Wood AR, Netherwood T, Ciarlet M, Imagawa H, Snodgrass DR (1996) Survey of equine rotaviruses shows conservation of one $\mathrm{P}$ genotype in background of two $\mathrm{G}$ genotypes. Arch Virol 141: 1601-1 612

36. Izuka M, Kaga E, Chiba M, Masamune O, Gerna G, Nakagomi O (1994) Serotype G6 human rotavirus sharing a conserved genetic constellation with natural reassortants between members of the bovine and AU-1 genogroups. Arch Virol 135: $427-432$

37. Kantharidis P, Dyall-Smith ML, Tregear GW, Holmes IH (1988) Nucleotide sequence of UK bovine rotavirus segment 4: possible host restriction of VP3 genes. Virology 166: 308-315

38. Kapikian AZ, Chanock RM (1996) Rotaviruses. In: Fields BN, Knipe DM, Howely PM, Chanock RM, Melnick JL, Monath TP, Roizman B, Straus SE (eds) Fields Virology, Vol. 2, 3rd ed. Lippincott-Raven Press, Philadelphia, pp 1657-1 708

39. Kelkar SD, Ray PG, Bedekar SS (1996) Assay of neutralizing antibodies to animal rotavirus strains and human rotavirus serotype G8 by a modified method in the residents of Pune, India. J Diarr Dis Res 14: 101-106

40. Kirkwood CD, Palombo EA (1997) Genetic characterization of the rotavirus nonstructural protein NSP4. Virology 236: 258-265

41. Kojima K, Taniguchi K, Kobayashi N (1996) Species-specific and interspecies relat- 
edness of the NSP1 sequences in human, porcine, bovine, feline and equine rotavirus strains. Arch Virol 141: 1-12

42. Li B, Hoshino Y, Gorziglia M (1996) Identification of a unique VP4 serotype that is shared by a human rotavirus (69M strain) and an equine rotavirus (H2-strain). Arch Virol 141: 155-160

43. Lu W, Duhamel GE, Hoshino Y, Benfield DA, Nelson EA, Hesse RA (1995) Characterization of the bovine group A rotavirus strain neonatal calf diarrhea virus-cody (NCDV-Cody). J Clin Microbiol 33: 990-994

44. Matsuno S, Hasegawa A, Mukoyama A, Inouye S (1985) A candidate for a new serotype of human rotavirus. J Virol 54: 623-624

45. Mattion NM, Mitchell DB, Both GW, Estes MK (1991) Expression of rotavirus proteins encoded by alternative open reading frames of genome segment 11. Virology 181: 295-304

46. Nakagomi O, Nakagomi T (1993) Interspecies transmission of rotaviruses studied from the perspective of genogroup. Microbiol Immunol 37: 337-348

47. Nakagomi T, Nakagomi O, Streckert HJ (1997) Bovine rotavirus strain 678 possesses VP4 serotype P7(5) specificity. Arch Virol 142: $1255-1262$

48. Newton K, Meyer JC, Bellamy AR, Taylor JA (1997) Rotavirus nonstructural glycoprotein NSP4 alters plasma membrane permeability in mammalian cells. J Virol 71: 9458-9463

49. Offit PA, Blavat G, Greenberg HB, Clark HF (1986) Molecular basis of rotavirus virulence: role of gene segment 4. J Virol 57: 46-49

50. Palombo EA, Bishop RF (1994) Genetic analysis of NSP1 genes of human rotaviruses isolated from neonates with asymptomatic infection. J Gen Virol 75: 3 635-3639

51. Rao CD, Das M, Ilango P, Lalwani R, Rao BS, Gowda K (1995) Comparative nucleotide and amino acid sequence analysis of the sequence specific RNA-binding rotavirus nonstructural protein NSP3. Virology 207: 327-333

52. Saitou N, Nei M (1987) The neighbour-joining method: a new method for reconstructing phylogenetic trees. Mol Biol Evol 4: 406-425

53. Sanger F, Nicklen S, Coulson AR (1977) DNA sequencing with chain-terminating inhibitors. Proc Natl Acad Sci USA 74: 5463-5 467

54. Santos N, Lima RCC, Pereira CFA, Gouvea V (1998) Detection of rotavirus types G8 and G10 among Brazilian children with diarrhea. J Clin Microbiol 36: 2727-2 729

55. Sato M, Nakagomi T, Tajima K, Ezura K, Akashi H, Nakagomi O (1997) Isolation of serotype G8, P6(1) bovine rotavirus from adult cattle with diarrhea. J Clin Microbiol 35: $1266-1268$

56. Snodgrass DR, Hoshino Y, Fitzgerald TA, Smith M, Browning GF, Gorziglia M (1992) Identification of four VP4 serological types (P serotypes) of bovine rotavirus using viral reassortants. J Gen Virol 73: 2319-2 325

57. Sukumaran M, Gowda K, Maiya PP, Srinivas TP, Kumar MS, Aijaz S, Reddy RR, Padilla L, Geenberg HB, Rao CD (1992) Exclusive asymptomatic neonatal infections by human rotavirus strains having subgroup I specificity and 'long' RNA electropherotype. Arch Virol 126: 239-251

58. Taniguchi K, Kojima K, Urasawa S (1996) Non-defective rotavirus mutants with an NSP1 gene which has a deletion of 500 nucleotides, including a cysteine-rich zinc finger motifencoding region (nucleotides 156 to 248 ) or which has a nonsense codon at nucleotides 153 to 155 . J Virol 70: 4 125-4 130

59. Taniguchi K, Urasawa T, Pongsuwanna J, Choonthanam M, Tayavasu C, Urasawa S (1991) Molecular and antigenic analysis of serotypes 8 and 10 of bovine rotaviruses in Thailand. J Gen Virol 72: 2929-2937 
60. Taniguchi K, Urasawa T, Urasawa S (1994) Species specificity and interspecies relatedness in VP4 genotypes demonstrated by VP4 sequence analysis of equine, feline and canine rotavirus strains. Virology 200: 390-400

61. Tian P, Estes MK, Hu Y, Ball JM, Zeng CQ, Schilling WP (1995) The rotavirus nonstructural glycoprotein NSP4 mobilizes $\mathrm{Ca}^{2+}$ from the endoplasmic reticulum. J Virol 69: 5763-5 772

62. Ward RL, Mason BB, Bernstein DI, Sander DS, Smith VE, Zandale GA, Rappaport RS (1997) Attenuation of a human rotavirus vaccine candidate did not correlate with mutations in the NSP4 protein gene. J Virol 71: 6267-6270

63. Xu L, Tian Y, Tarlow O, Harbour D, McCrae MA (1994) Molecular biology of rotaviruses IX. Conservation and divergence in genome segment 5. J Gen Virol 75: 3413-3 421

64. Zhang M, Zeng CQY, Dong Y, Ball JM, Saif LJ, Morris AP, Estes MK (1998) Mutations in rotavirus nonstructural glycoprotein NSP4 are associated with altered virus virulence. J Virol 72: 3 666-3672

Authors' address: Dr. C. Durga Rao, Department of Microbiology and Cell Biology, Indian Institute of Science, Bangalore 560 012, India.

Received September 29, 1999 